Szegedi Tudományegyetem, Fogorvostudományi Kar, Konzerváló- és Esztétikai Fogászati Tanszék*

Szegedi Tudományegyetem, Fogorvostudományi Kar, Szájsebészeti Tanszék**

Semmelweis Egyetem, Fogorvostudományi Kar, Arc-, Állcsont-, Szájsebészeti- és Fogászati Klinika**

\title{
Az endodonciai mikrosebészet helye napjainkban - irodalmi áttekintés
}

\author{
DR. FRÁTER MÁRK*, DR. ANTAL MÁRK*, DR. BRAUNITZER GÁBOR**, DR. JOÓB-FANCSALY ÁRPÁD ${ }^{\star \star *}$, DR. NAGY KATALIN**
}

\begin{abstract}
A röntgenfelvétel alapján megfelelőnek ítélt, az endodonciai ellátás ellenére is perzisztáló apikális elváltozással érintett fogak megmentésére utolsó lehetőségként áll rendelkezésre az endodonciai sebészet. Az endodonciai sebészeti beavatkozás elsődlegesen azokban az esetekben javasolt, amikor nem sebészi terápia kivitelezése nem lehetséges, a hagyományos ortográd kezeléssel nem várható javulás, vagy ha biopszia válik szükségessé. A hagyományos endodonciai sebészet esetében a gyökércsúcs 45 fokos leferdítése, majd a gyökércsatorna retrográd (fúróval történő) előkészítését követően elvégzett gyökértömések sikeressége nem mindig felel meg az elvártaknak. Az említett sikeresség jelentősen javult a mikrosebészeti eszközök és az operációs mikroszkópok használatának elterjedésével, valamint az ultrahangos retropreparáció lehetőségének bevezetésével. Jelen összefoglaló tanulmány célja, hogy a legjelentősebb, megfelelő metodikával és kellő esetszámmal rendelkező nemzetközi közlemények áttekintésével a mindennapi gyakorlatban is használható segítséget nyújtson a modern endodonciai mikrosebészeti beavatkozások kivitelezéséhez.
\end{abstract}

Kulcsszó: endodonciai mikrosebészet, endodonciai sebészet, mikroszkóp, gyökércsúcs-rezekció, retrokavitás, MTA

\section{Bevezetés}

Az endodonciai terápia célja a periapicalis elváltozás kialakulásának megakadályozása, illetve a már meglévő periapicalis elváltozás gyógyítása [27]. Az endodonciai sebészeti beavatkozás általában a periapicalis elváltozások kezelésének utolsó lehetőségeként merül fel, pl. periapicalis ciszta, komplex anatómiájú gyökércsatorna, extraradikuláris infekció, vagy újrakezelés és újra elvégzett gyökértömés (revízió) után sem gyógyult elváltozások esetén [14].

Jelen közlemény célja a Medline adatbázisban a Pubmed és Sciencedirect keresőprogramokkal, az „endodontic microsurgery, surgical endodontics, apicoectomy, retropreparation" kulcsszavakra keresve fellelhetö, 1982-2014 közötti időtartam alatt publikált nemzetközi közlemények áttekintése, a megtalálható eredmények összefoglalása és egy általános irányelv elkészítése, amely a fogorvos kollégák számára segítségül szolgálhat az endodonciai mikrosebészeti beavatkozások tervezéséhez és kivitelezéséhez.

\section{Endodonciai mikrosebészeti beavatkozások indikációi}

Az Európai Endodonciai Társaság (European Society of Endodontology, ESE) legutóbb 2006-ban módosította az endodonciai mikrosebészeti beavatkozások indikációit [11]. Az új ajánlások a következők:
- Periapicalis elváltozás röntgentünettel és/vagy szubjektív panasszal, elzáródott, beszűkült gyökércsatornájú fognál. Az elzáródás, az akadály nem tűnik eltávolíthatónak vagy túl nagy a veszélye a gyökér kritikus károsodásának, perforációjának

- Gyökércsúcson túljutott gyökértömő anyag, mellyel összefüggésben (vagy ettől függetlenül) a kezelendő fog periapicalis elváltozás röntgen- és/vagy klinikai tüneteit mutatja, még hosszabb idő után is

- Gyökérkezelés és gyökértömés után fennmaradó vagy növekedő periapicalis elváltozás, revízió lehetősége nélkül

- Perforáció a gyökércsatorna vagy a pulpakamra területén a pulpaür felől (ortográd irányból) nem kezelhető lokalizációban

\section{Konvencionális endodonciai sebészet és endodonciai mikrosebészet}

Korábban az endodonciai sebészet leginkább az endodonciai beavatkozásokat kiegészító hagyományos sebészi terápiát (rezekció és kürettázs) jelentette. Mára azonban az ebben az értelemben vett endodonciai sebészet élesen elkülönül a modern felszereltség (mikroszkóp, ultrahangos preparáló eszközök stb.) mellett elvégzett endodonciai mikrosebészettől. A megkülönböztetést a beavatkozások sikeressége is indokolja: az endodonciai mikrosebészeti beavatkozások sikeressége $(93,5 \%)$ jóval meghaladja az endodonciai sebészeti 
beavatkozásokét (59,0\%) [27]. A sikertelen esetek kapcsán extrahált fogak operációs mikroszkóppal történő vizsgálata kimutatta, hogy hagyományos endodonciai sebészeti módszerekkel és eszközparkkal komplex apikális anatómiai konfigurációk kielégítő lokalizációja, kitisztítása és tömése nem lehetséges [15]. Erre a problémára jelent megoldást az endodonciai mikrosebészet eszköztára és módszertana.

\section{Mikroszkóp az endodonciai sebészi terápiában}

Az endodonciai mikrosebészet lényegében egyesíti a mikroszkóp által nyújtott nagyítás és megvilágítás előnyeit az új mikroeszközök alkalmazásával $[16,7]$.

Annak ellenére, hogy a mindennapi fogászatban vitatott a mikroszkóp alkalmazása, a konvencionális (ortográd) és sebészeti endodonciában való alkalmazása az USA-ban már az 1990-es évek óta rutinnak számít, 1998 óta pedig részét képezi a posztgraduális oktatásnak is [2].

A mikroszkóp használata lehetővé teszi a gyökércsatorna szükületének és járulékos csatornáinak azonosítását [3], emellett segíti az iatrogén komplikációk, eszközfraktúrák vagy egyéb, a gyökércsatorna átjárhatóságát akadályozó képletek (pl. calcificatio) kezelését, eltávolítását is. Külön javasolt a nagyítás alkalmazása festék használatával kiegészítve gyökércsúcs-rezekció után a rezekált apikális vég vizsgálatára, feltáratlan gyökércsatorna vagy dentinrepedések lokalizálása érdekében [15]. Általában elmondható, hogy a mikroszkóp precízebb terápiát tesz lehetővé az endodonciai sebészeti kezelés minden egyes lépése során (lebenyalakítás, rezekció, gyökércsúcs retrográd preparálása stb.). [3].

Mindezeket tekintetbe véve kijelenthető, hogy a modern fogászatban az apicalis sebészeti beavatkozás kellő nagyítás alkalmazása nélkül nem tud megfelelni a mai kor professzionális szakmai elvárásainak. A nagyítás mellőzése mind az endodontus, mind a páciens szempontjából hátrányos. Kim és mtsai vizsgálatukban azt találták, hogy az endosebészeti munkájuk során mikroszkópot használó fogorvosok szerint csak mikroszkóppal lehet detektálni a kulcsfontosságú részeket [15] (I. táblázat). Alapvető különbség látható a mikroszkóppal [8] és a nem mikroszkóppal [30] végzett apikális sebészeti beavatkozások sikeressége között.

\section{Sikeresség}

A bizonyítékon alapuló orvoslás lényege, hogy különböző terápiás eljárások között a rendelkezésre álló bizonyítékok, adatok alapján érdemes dönteni. Mára a fogorvoslásban is teret nyert a bizonyítékokon alapuló szemlélet. A megfelelő döntéshez ismernünk kell a lehetséges beavatkozásokat és ezek várható sikerességét. Sikertelen endodonciai beavatkozást követően a következő terápiás lehetőségek jönnek szóba:

1. revízió

2. endodonciai sebészeti beavatkozás

3. endodonciai mikrosebészeti beavatkozás

4. fogeltávolítás után fix pótlás

5. implantáció

A revízió sikeressége 77-78\% [32], endodonciai sebészeti beavatkozások esetén nagyjából 59\% [28], míg endodonciai mikrosebészeti beavatkozások esetén hozzávetőlegesen 94\% [28], fix pótlások esetén 89\% [23], implantátumok esetén a sikeresség pedig 94,5-96,8\% [13]. Mivel azonban a sikeresség definíciója a különböző beavatkozások tekintetében, valamint sokszor egyazon beavatkozás esetében sem egységes, az egyes alternatívák közvetlen összehasonlítása nem egyértelmú. A sikerességet leggyakrabban Rud és Andreasen [24], illetve Molven [22] kritériumai alapján értékelik, amely kritériumrendszerek alapján beszélhetünk sikerességről, sikertelenségről, és a két kategória között található túlélésről. Túlélés alatt általában klinikai tünetektől mentes funkcionális megtartást értünk, mely sok esetben nem jelent teljes sikerességet. Egyes esetekben (pl. implantátumok és fix pótlások) a két fogalom jelentése gyakorlatilag megegyezik, ugyanakkor primer endodonciai beavatkozásoknál, revíziónál és endodonciai mikrosebészeti beavatkozásoknál a túlélés a sikerességnek csak egy alacsonyabb minőségi fokát jelenti [32].

Fontos kiemelni, hogy a hagyományos endodonciai sebészeti beavatkozások sikeressége az idő előre haladtával csökken (2-4 év után 77,8\%-ban, 4-6 év után $71,8 \%$-ban, míg 6 évnél hosszabb követéses idő után az esetek 62,9\%-ban) [32], viszont a modern endodonciai mikrosebészeti beavatkozások alkalmazásával szignifikánsan jobb eredmény érhető el hosszabb követési idő után is, mint hagyományos endodonciai sebészeti beavatkozás során [27, 28, 34].

A következőkben arra térünk ki, hogy az endodonciai

Endodonciai sebészeti terápiákhoz, stratégiákhoz tartozó nagyítások (Kim és Kratchman, 2006. alapján)

\begin{tabular}{|l|c|l|}
\hline Osztályozás & Nagyítás & Terápia, stratégia \\
\hline Alacsony & $\times 4-\times 8$ & Orientáció, inspekció, oszteotómia, sebészi fúrók, végek behelyezése, gyökércsúcs-preparáció, sutura \\
\hline Közepes & $\times 8-\times 14$ & $\begin{array}{l}\text { A legtöbb sebészi beavatkozás, pl. granulációs szövet eltávolítása, gyökércsúcs feltérképezése, } \\
\text { retrográd preparáció, retrográd tömés, vérzéscsillapítás }\end{array}$ \\
\hline Magas & $\times 14-\times 26$ & Rezekált gyökérfelszín vizsgálata, retrográd tömés vizsgálata, dokumentáció \\
\hline
\end{tabular}


mikrosebészeti beavatkozások mely lépésein keresztül, hogyan valósulhat meg ezen beavatkozások nagyobb sikeressége a hagyományos endodonciai sebészeti beavatkozásokhoz képest.

\section{Lebenyképzés és a lágyszövetek kezelése}

Az endodonciai mikrosebészet a lebenyképzésben és a lágyszövetek kezelésében is változásokat hozott. A semilunaris lebenyképzés, mely korábban a frontfogak esetében az egyik legnépszerübb technika volt, már nem javasolt, a nem megfelelő hozzáférés és a kedvezőtlen hegképződés miatt [18]. Korábban mind a submarginalis teljes vastagságú, mind a mucoperiostealis lebeny esetében szélesebb apicalis rész kialakítását javasolták a lebeny jobb keringésének biztosítása érdekében. Ez szükségtelennek bizonyult és növelte a hegképződés kockázatát is. A modern endodonciai mikrosebészeti irányelvek szerint a bázis szélessége nem haladhatja meg a cervicalis szélességet, a verticalis metszések pedig követik a lebenyt ellátó erek lefutását, a hegképződés minimalizálása érdekében. A sulcularis teljes vastagságú lebeny alkalmazásának fő hátránya a papilla magasságának csökkenése és a létrejött recesszió [35]. Marginalis mucoperiostealis lebeny kialakításakor Velvart a papillaprezervációs technikát javasolja a papillamagasság-csökkenés minimalizálására [36].

Emellett javasolt a papilla-alapú, intrasulcularis metszéstípus, amely elősegíti az interdentális papilla magasságának megtartását [35].

A korábban ajánlott egy héttel szemben a varratokat 48-72 órán belül javasolt eltávolítani, különös tekintettel arra, hogy a lebeny újratapadásához ennyi idő is elegendő, ráadásul 72 órán túl a lágyszövetek hajlamosak a varratokra ránőni. A korábbi 4,0 vastagsággal szemben az újabb varróanyagok 5,0 vagy 6,0 vastagságúak, ami elősegíti a gyorsabb gyógyulást. Nem javasolt a selyemfonal alkalmazása sem, mivel a selyem elösegíti a plakk-képződést, ezáltal hátráltatva a gyógyulást $[16,7]$.

\section{Vérzéscsillapítás}

A vérzéscsillapítás egyik legfontosabb eleme az első bemetszés előtt elvégzett alapos infiltrációs érzéstelenítés, ugyanis ha lebenyalakítás után adunk pótlólag érzéstelenítést, az már nem fejt ki komolyabb vérzéscsillapító hatást. A lebenyalakítás és a csontüreg kialakítása után a perioperatív vérzéscsillapítás esszenciális, mivel segíti a gyökércsúcs vizsgálatát, valamint a rezekciót követő retrográd gyökértömés alatt a megfelelő izolálást is. Lokális vérzéscsillapításra az évek során számos anyagot használtak, úgymint sebészeti viasz, kollagén, thrombin, Gelfoam ${ }^{\circledR}$, Surgicel ${ }^{\circledR}$, kálcium-szulfát, vas-szulfát, valamint adrenalin tartalmú szivacsok. Ezek közül a modern endodonciai mikrosebészetben az utóbbi 3 anyagot használják. Az adrenalin tartalmú szivacsok lokális vazokonstrikciós hatásuk által okoznak azonnali vérzéscsillapítást, a vas-szulfát lokális koaguláns, a kálcium-szulfát pedig egyszerüen eltömeszeli az átmetszett kapillárisokat. Jelentős különbség a két utóbbi anyag között, hogy a vas-szulfátnak citotoxikus hatása van, emiatt a varratok behelyezése előtt teljesen el kell távolítani a csontüregből, kálcium-szulfát esetében viszont ez nem szükséges. Egyes szerzők szerint a kalcium-szulfát hatékonysága meghaladhatja a vasszulfát hatékonyságát [25]. A leghatásosabbak mégis az adrenalin tartalmú vatták. Ezeket sokáig félve alkalmazták cardiovascularis alapbetegség esetén, jelentős szisztémás hatást azonban nem sikerült igazolni [38], ezért használatuk biztonsággal javasolható.

\section{Osteotomia}

Intakt perioszteum esetében szükséges valamilyen szintű osteotomia létrehozása. Ez történhet sebészi fúróval, csonttrepánnal, illetve akár piezosebészeti eszközzel is. Egyes közlemények már megemlítik a CBCT-vizsgálat és 3D nyomtatással létrehozott sebészi sablonok használatát is, de erre a nemzetközi irodalomban még nincs megalapozott vizsgálat. Majmokon végzett vizsgálat alapján, ha a periapicalis lézió mérete következtében a csontüreg átmérője nagyobb, mint 15-20 mm, akkor nem kívánatos lágyrész-proliferáció, és ennek következtében elégtelen csonttelődés jöhet létre [26]. Emberben az irodalom az $5 \mathrm{~mm}$-es [14] és a $10 \mathrm{~mm}$-es [5] átmérőt nevesíti, mint olyan kritikus határt, amely alatt jelentősen nagyobb a gyors, komplikációmentes gyógyulás esélye. Elsődleges szabályként azonban mindig a lehető legkisebb csontveszteségre kell törekedni.

\section{Rezekció, retropreparálás}

Az endodonciai mikrosebészeti beavatkozás kulcsfontosságú lépései a gyökércsúcs rezekciója, a retrokavitás (a gyökércsatorna lefutásának megfelelő, ultrahangos eszközzel, apikális irányból koronális irányba kialakított kavitás) preparálása és a gyökércsatorna lezárása retrográd gyökértöméssel.

A gyökércsúcs-rezekció mértékének meghatározásakor fontos szempont a fog helyreállíthatósága, későbbi végleges restaurálhatósága, és az ezt meghatározó gyökér-korona arány. Ha a fogat körülvevő csont mennyisége és/vagy minősége nem megfelelő, vagy a rezekció elvégzésével a gyökér-korona arány a későbbi stabilitás szempontjából előnytelenül alakulna, abban az esetben megfontolandó az endodonciai mikrosebészeti beavatkozás alkalmazhatósága. Ha a gyökér-korona arány kielégítő, akkor minden esetben $3 \mathrm{~mm}$ nagyságú gyökércsúcsi szakasz rezekálandó. Kim és mtsai kimutatták, hogy a rezekció során eltávolított $3 \mathrm{~mm}$ nagyságú gyökércsúccsal az oldalcsator- 
nák 93\%-át és az egyéb elágazódások, ramifikációk, delták 98\%-át sikerül eltávolítani (1. ábra) [15].

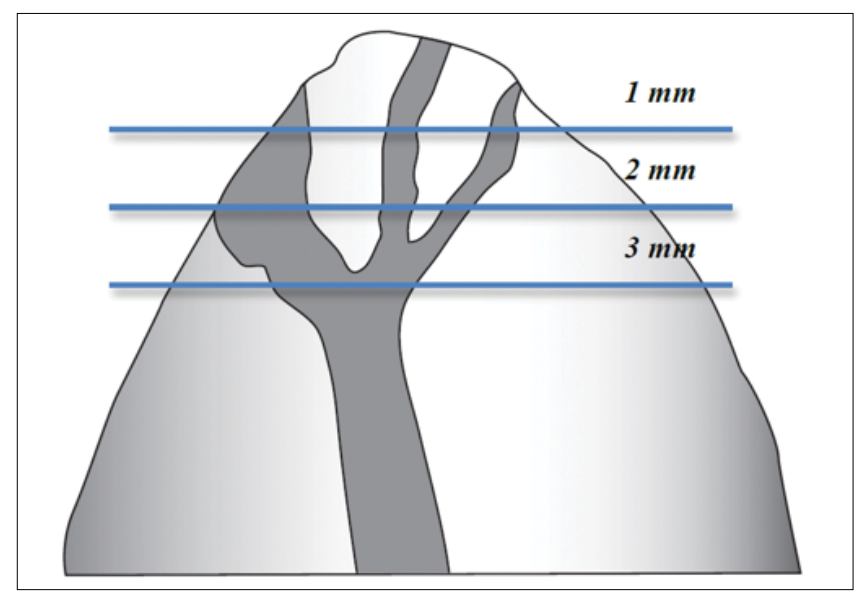

1. ábra: Az apikális ramifikációk csak minimálisan $3 \mathrm{~mm}$ eltávolításakor eliminálhatók (Kim és mtsai 2001)

A rezekció szögét elsősorban a rezekcióra és retropreparálásra használt eszköz geometriája és a gyökércsúcshoz való hozzáférése határozza meg. Régebben gyakori volt a 30-45 fokos vagy annál nagyobb rezekciós szög. Különböző vizsgálatokban azóta kimutatták, hogy minél nagyobb a rezekció szöge (a 0 fok a gyökér apicalis részének tengelyére fektetett merőlegesnek felel meg), annál több dentintubulus nyílik meg [31]. A dentintubulusok megnyílása kedvez a periapicalis terület bakteriális inváziójának [21], végső soron pedig a terápia kudarcát okozhatja. Cél tehát a 0 fokos rezekciós szög minél stabilabb megtartása. Gilheany és mtsai közleményükben [12] a következő megállapításokat foglalták össze:

1. a rezekció szögét növelve szignifikánsan nő az apicalis szivárgás mértéke

2. növelve a retrográd gyökértömés mélységét, csökken az apicalis szivárgás mértéke és

3. a rezekció szögének megfelelően az „ideális” retropreparálás minimális mélysége a következő:

0 fok $=1 \mathrm{~mm}, 30$ fok $=2,1 \mathrm{~mm}, 45$ fok $=2,5 \mathrm{~mm}$.

Gyökércsúcs-rezekció és retropreparálás tekintetében ezek mellett is a „3+3"-szabály [4] az irányadó, amely szerint a legtöbb anatómiai anomália a gyökércsatorna apicalis $3 \mathrm{~mm}$-én belül van, emiatt az apicalis $3 \mathrm{~mm}$-t kell rezekálni, majd $3 \mathrm{~mm}$-t retropreparálni.

A retropreparáció célja egy tiszta, jól megformált I. osztályú kavitás kialakítása a rezekció után maradt apicalis részben, amelynek követnie kell a gyökércsatorna lefutását. A kavitás elsődleges funkciója a tömőanyag megtartása. Mivel az endodonciai mikrosebészeti beavatkozás sikeressége nagyban függ a retrográd gyökértöméstöl, azaz a gyökércsatorna megfelelő apicalis lezárásától, a kavitás optimális kialakítása alapvető fontosságú $[7,4]$.
Az ideális retropreparálással szembeni követelmények a következők [7]:

- követi a gyökércsatorna lefutását

- apicalis 3 mm kitisztítása és megformázása

- megfelelően retentív retrokavitás

- isthmus feltárása

- dentinfalak ne legyenek meggyengítve

Napjainkban a retropreparáláshoz ultrahangos eszközöket javasolnak, melyek alakjuknál fogva lehetőséget biztosítanak a megfelelő formájú, tengelyállást követő, isthmust is involváló retrokavitás kialakítására. Az ezzel kapcsolatos irodalmi adatok ellentmondásosak. Több tanulmány számol be az ultrahangos eszközfejek használata során kialakuló dentinrepedésekről [19, 1], míg más tanulmányok cáfolták, hogy ezek az ultrahangos eszköz alkalmazása miatt alakulnak ki [10]. Végső soron elmondható, hogy a repedés kialakulásának valószínűsége az eszköz alkalmazásának erősségétől, az alkalmazott fokozattól és az applikációs időtől függ [37], ezért érdemes ezeket az eszközöket közepes fokozaton, nem erőltetve, folyamatos vízhǔtés mellett használni.

Abban az esetben, ha a rezekció során a $3 \mathrm{~mm}$ nagyságú gyökércsúcs-eltávolítás nem végezhető el (előnytelenül alakulna a gyökér-korona arány, ami veszélyezteti a fog stabilitását, vagy intraradikuláris csap nem teszi lehetővé, mert utána már nem maradna hely a gyökértömést megtartó retrokavitás kialakítására), módosított rezekció és retropreparálás végezhető. A módosított rezekció és retropreparálás során két preparálási mód lehetséges [17]: 1 . kupolapreparálás vagy 2 . „sapkázás". 1. A kupolapreparálásnál egy $1 \mathrm{~mm}$ mélységü, homorú, kupola formájú bevágást preparálunk az apexbe. Ez történhet ultrahangos eszközzel vagy akár acélfúróval is. Ezt a bevágást zárjuk le ezután egy réteg adhezívvel és kompozit alapú retrográd gyökértömő anyaggal. 2. A „sapkázás” során a jól hozzáférhető apexet óvatosan felérdesítjük, majd adhezívvel és egy réteg kompozit alapú anyaggal bevonjuk, lezárva a szivárgási kockázatot jelentő területeket, oldalcsatornákat. llyen esetekben azért indokolt kompozit alapú retrográd gyökértömő anyagok alkalmazása (pl.: Retroplast), mert jóval kisebb rétegvastagságnál is képesek megfelelő apicaliszárást biztosítani. Ezen anyagok alkalmazása ugyanakkor olyan fokú haemostasishoz és szárazsághoz kötött, ami nem mindig elérhető.

\section{A gyökércsúcs vizsgálata}

A rezekció után rendkívül fontos a rezekált felszín megfestése (metilénkék) és annak precíz vizsgálata [16]. Ebben a lépésben kell megvizsgálni, hogy találunk-e kalcifikálódott, fel nem tárt gyökércsatornát, isthmust, nem megfelelően záró gyökértömést, amelyek a korábbi sikertelenséget magyarázhatják [15]. A különálló gyökércsatornákat összekötő isthmust minden esetben fel kell tárni, mivel az baktérium-rezervoárt képez. Camb- 
ruzzi és Marshall 1983-as közleményének [6] megjelenéséig nem tulajdonítottak jelentőséget az isthmusoknak. A későbbiekben bebizonyosodott [16], hogy a felső hatos fogak MB gyökere az esetek $90 \%$-ában, az alsó hatos fogak $M$ gyökere az esetek $80 \%$-ában, és a felső és alsó premolárisok az esetek $30 \%$-ában tartalmaznak isthmust, így azok nem megfelelő feltárása és kitisztításának hiánya jelentős fertőzési kockázatot hordoz magában.

\section{Retrográd gyökértömés}

A retrográd gyökértömő anyagokkal szembeni követelmények Kohen szerint [17] a következők:

- jó záródás, amely nem engedi, hogy a gyökércsatornában maradt baktériumok

és toxinjaik kijussanak a periapicalis térbe,

- ne szívódjon fel,

- ne oldódjon szöveti folyadékban,

- biokompatibilis és dimenzióstabil legyen,

- cementogenezist hozzon létre,

- könnyen lehessen adaptálni,

- ideális legyen a keverési és a kötési ideje.

Kívánatos továbbá, hogy röntgenárnyékot adjon, nedvességre ne legyen érzékeny, és rendelkezzen baktericid/bakteriosztatikus tulajdonsággal. A napjainkban használt retrográd gyökértömő anyagok a cink-oxid-eugenol tartalmú cementek (IRM és Super-EBA cementek), rezinnel módosított üvegionomer cement, kompozit és az MTA (mineral trioxide aggregate). Jelenleg nincs olyan retrográd gyökértömő anyag, amely az öszszes kívánalomnak eleget tenne.

Az említett anyagok közül leggyakrabban az MTA-t, az IRM-et vagy a Super-EBA cementet használják, ezek kiemelkedő terápiás sikeressége miatt. Az MTA és az IRM rendelkezik a legjobb antibakteriális hatással, bár egyes baktériumtörzsekkel szemben ez a hatás nem kielégítő [9]. Az MTA-nak és a Super-EBA cementnek kiváló a széli záródása [20], bár ez nem látszik korrelálni a klinikai sikerességgel [29]. Mindenképpen kiemelendő az MTA biokompatibilitása, és egyedülálló a cementképzést és csontképzést stimuláló hatása [33]. További előnye, hogy nedvesen is megköt. Egyedüli hátránya az applikáció nehezebb kivitelezése. A rendelkezésre álló adatokat összevetve azt mondhatjuk, hogy az MTA rendelkezik a legideálisabb tulajdonságokkal a retrokavitás tömésére.

\section{Irodalom}

1. Abedi HR, Mierlo Bl Van, Wilder-Smith P, Torabinejad M: Effects of ultrasonic root-end cavity preparation on the root apex. Oral Surg Oral Med Oral Pathol Oral Radiol Endod. 1995; 207-213.

2. American Dental Association: Commission on Dental Accreditation. Accreditation Standards for Advanced Specialty Education
Programs in Endodontics. Chicago, 2008. http://www.ada.org/ sections/educationAndCareers/pdfs/endo.pdf. (2011.11.08.)

3. Arx T Von: Frequency and type of canal isthmuses in first molars detected by endoscopic inspection during periradicular surgery. Int Endod J. 2005; 160-168.

4. Arx T Von, Kurt B, Ilgenstein B, Hardt N: Preliminary results and analysis of a new set of sonic instruments for root-end cavity preparation. Int Endod J. 1998; 32-38.

5. Barone C, Dao TT, Basrani BB, Wang N, Friedman S: Treatment outcome in endodontics: the Toronto study-phases 3,4 , and 5 : apical surgery. $J$ Endod. 2010; 28-35.

6. Cambruzzi JV, Marshall FJ: Molar endodontic surgery. J Can Dent Assoc. 1983; 61-65.

7. CARR GB: Surgical endodontics. In CoHen S, Burns R, (ed.): Pathways of the pulp. (6th ed.) Mosby, St Louis, 1994; 531.

8. Chong BS, PITT Ford TR, Hudson MB: A prospective clinical study of Mineral Trioxide Aggregate and IRM when used as root-end filling materials in endodontic surgery. Int Endod J. 2003; 520-526.

9. Eldeniz aU, hadimli HH, Ataoglu h, Orstavik D: Antibacterial effect of selected root-end filling materials. J Endod. 2006; 345-349.

10. Engel TK, Steiman HR: Preliminary investigation of ultrasonic root end preparation. J Endod. 1995; 443-445.

11. European Society of Endodontology. Quality guidelines for endodontic treatment: consensus report of the European Society of Endodontology. Int Endod J. 2006; 921-930.

12. Gilheany PA, Figdor D, Tyas MJ: Apical dentin permeability and microleakage associated with root end resection and retrograde filling. J Endod. 1994; 22-26.

13. Jung Re, PJetursson Be, Glauser R, Zembic A, Zwahlen M, Lang NP: A systematic review of the 5-year survival and complication rates of implant-supported single crowns. Clin Oral Implants Res. 2008; 119-130.

14. Karabucak B, Setzer F: Criteria for the ideal treatment option for failed endodontics: surgical or nonsurgical? Compend Contin Educ Dent. 2007; 304-310.

15. Kim S, Kratchman S: Modern endodontic surgery concepts and practice: a review. J Endod. 2006; 601-623.

16. KIM S, PECORA G, RuBinsteIn R: Comparison of traditional and microsurgery in endodontics. In KIM S, PECORA G, RUBINSTEIN R (ed.): Color atlas of microsurgery in endodontics. W.B. Saunders, Philadelphia, 2001; 5-11.

17. Kohen S, Hargreaves KM (ed): Pathways of the pulp. (9th ed.) Mosby, Elsevier, St. Louis, 2006.

18. Kramper BJ, Kaminski EJ, Osetek EM, Heuer MA: A comparative study of the wound healing of three types of flap design used in periapical surgery. $J$ Endod. 1984; 17-25.

19. Layton CA, Marshall JG, Morgan LA, Baumgartner JC: Evaluation of cracks associated with ultrasonic root-end preparation. $J$ Endod. 1996; 157-160.

20. Maltezos C, Glickman GN, Ezzo P, He J: Comparison of the sealing of Resilon, Pro Root MTA, and Super-EBA as root-end filling materials: a bacterial leakage study. J Endod. 2006; 324-327.

21. Mehlhaff DS, Marshall JG, Baumgartner JC: Comparison of ultrasonic and high-speed-bur root-end preparations using bilaterally matched teeth. J Endod. 1997; 448-452.

22. Molven O, Halse A, Grung B: Observer strategy and the radiographic classification of healing after endodontic surgery. Int J Oral Maxillofac Surg. 1987; 432-439.

23. PJetursson BE, Tan K, Lang NP, Brägger U, Egger M, Zwahlen M: A systematic review of the survival and complication rates of fixed partial dentures (FPDs) after an observation period of at least 5 years. Clin Oral Implants Res. 2004; 667-676.

24. Rud J, AndREAsen JO, Jensen JE: Radiographic criteria for the assessment of healing after endodontic surgery. Int J Oral Surg. 1972; 195-214.

25. Scarano A, Artese l, Piattelli A, Carinci F, Mancino C, Iezzi G: Hemostasis control in endodontic surgery: a comparative study of calcium sulfate versus gauzes and versus ferric sulfate. J Endod. 2012; 20-23. 
26. Schmitz JP, Hollinger JO: The critical size defect as an experimental model for craniomandibulofacial nonunions. Clin Orthop Relat Res. 1986; 299-308.

27. Setzer FC, Kohl MR, Shah SB, Karabucak B, Kim S: Outcome of endodontic surgery: a meta-analysis of the literature-Part 2: Comparison of endodontic microsurgical techniques with and without the use of higher magnification. J Endod. 2012; 1-10.

28. Setzer FC, Shah SB, Kohli MR, Karabucak B, Kim S: Outcome of endodontic surgery: a meta-analysis of the literature-part 1: Comparison of traditional root-end surgery and endodontic microsurgery. J Endod. 2010; 1757-1765.

29. Song M, KIM E: A prospective randomized controlled study of mineral trioxide aggregate and super ethoxy-benzoic acid as root-end filling materials in endodontic microsurgery. J Endod. 2012; 875-879.

30. Testori T, Capelli M, Milani S, Weinstein RL: Success and failure in periradicular surgery: a longitudinal retrospective analysis. Oral Surg Oral Med Oral Pathol Oral Radiol Endod. 1999 493-498.

31. Tidmarsh BG, Arrowsmith MG: Dentinal tubules at the root ends of apicected teeth: a scanning electron microscopic study. Int Endod J. 1989; 184-189.
32. Torabinejad M, Corr R, Handysides R, Shabahang S: Outcomes of nonsurgical retreatment and endodontic surgery: a systematic review. J Endod. 2009; 930-937.

33. Torabinejad M, PariRoKh M: Mineral trioxide aggregate: a comprehensive literature review-part II: leakage and biocompatibility investigations. J Endod. 2010; 190-202.

34. Tsesis I, Rosen E, Schwartz-Arad D, Fuss Z: Retrospective evaluation of surgical endodontic treatment: traditional versus modern technique. J Endod. 2006; 412-416.

35. Velvart P: Papilla base incision: a new approach to recessionfree healing of the interdental papilla after endodontic surgery. Int Endod J. 2002; 453-460.

36. Velvart P, Ebner-Zimmermann U, Ebner JP: Comparison of longterm papilla healing following sulcular full thickness flap and papilla base flap in endodontic surgery. Int Endod J. 2004; 687-693.

37. Wright HM JR, Loushine RJ, Weller RN, Kimbrough WF, Waller J, PASHLEY DH: Identification of resected root-end dentinal cracks: a comparative study of transillumination and dyes. J Endod. 2004; 712-715.

38. Vy CH, Baumgartner JC, Marshall JG: Cardiovascular effects and efficacy of a hemostatic agent in periradicular surgery. $J$ Endod. 2004; 379-383.

\section{Fráter M, Antal M, Braunitzer G, Joób-Fancsaly Á, Nagy K}

\section{An update on endodontic microsurgery - a literature review}

Surgical endodontic treatment has long been the last resort for saving previously root canal treated teeth with persistent chronic apical periodontitis. Surgical endodontic treatment could be indicated when nonsurgical retreatment seems impractical or unlikely to improve the previous results or when a biopsy is needed. Traditional surgical endodontic treatment is performed with root-end resection with a 45-degree bevel, retrograde preparation of the canal with bur, and root-end filling leading to only a moderate success rate with this technique. This changed with the introduction of the microscope, microinstruments, ultrasonic tips, and more biologically acceptable root-end filling materials (e.g. mineral trioxide aggregate (MTA), bioceramics). By the utilisation of the above mentioned improvements during the procedure, the achieved success rate can be significantly higher $(93,5 \%)$ compared to the traditional surgical endodontic procedure $(59 \%)$. Nevertheless it must be emphasized that this increased success rate can only be obtained if all steps with key importance (i.e. root tip resection, retrograde cavity preparation and retrograde obturation) are performed according to the modern, evidence-based methods. The aim of this article is to impart the advancements in this field in the used materials, techniques and theories, providing a contemporary perspective of modern „endodontic microsurgery”.

Keywords: endodontic microsurgery, surgical endodontics, apicectomy, retropreparation, microscope, MTA. 